$\underline{\beta}=-m$

\title{
Phytochemical evaluation and exploration of the hepatoprotective activity of 5 different formulations in CCL4 induced albino RATS
}

\author{
Patel Hardik R ${ }^{1 *}$, Patel Nilesh ${ }^{2}$, Patel Janmejay ${ }^{1}$, Patel Payal ${ }^{1}$, Patel Apurva ${ }^{1}$ \\ ${ }^{1}$ Petlad Mahal Arogya Mandal Pharmacy, Piplata, Nadiad, Gujarat, India \\ ${ }^{2}$ Shree S. K. Patel College of Pharmaceutical Education \& Research, Kherva, Mehsana \\ *Corresponding author E-mail: Hardzpharma19987@gmail.com
}

\begin{abstract}
Background: Hepatotoxicity and Liver disorders are chronic disorders due to different causes. It affects people in their prime of life, predominantly between the ages of 25-75 years with unpredictable courses. The different formulations are assumed to have significant activity in the treatment of the Liver disorders.

Objective: The present study planned to evaluate the synergistic efficacy activity of the different formulations using CCL4 induced hepatotoxic model albino rats.

Materials \& Methods: The Phytochemical analysis of the T.cordifolia and five different formulations were performed. The animals were divided into eight different groups of 6 animals each as CCl4 treated, Single Plant extracts treated and another different test drug treated groups except 1st group, which was treated with only normal saline. The drugs were administered orally, twice a day and continued for 20 days. On the last day, all the group of animals were treated with the $1 \mathrm{ml} / \mathrm{kg} \mathrm{CCl} 4$ I.P. The Statistical significance was assessed using One-way ANOVA.

Results: It was observed that 5 different formulations, i.e. Herbolive Syrup, Hepatonej Syrup, Hepanej Capsule, Herbolive Capsule, and Hepatonej Capsule produced significant hepatoprotective effect on 21st day. All the Formulations have significantly reduced the elevated level of Total Bilirubin, Direct Bilirubin, SGPT, SGOT, and ALP level.

Conclusion: The result reveals that all the Herbomineral formulations possess the better hepatoprotective activity compare to single T.cordifolia plant extract. It is due to synergistic action of the various plants and minerals used into the formulation which brings down the elevated liver damage parameter to almost normal level.
\end{abstract}

Keywords: ALP; CCl4; SGOT; SGPT; Hepato Protective; Herbomineral Formulations.

\section{Introduction}

The maintenance, performance, and regulation of the Homeostasis in our body is an important role of the Liver; it is also involved in various biochemical pathways to growth and fight against diseases, nutrient supply, energy provision and reproduction. Hence it is very important to maintain healthy liver for overall health. On another side, liver is also tend to expose to exogenous substances like environmental toxins, drugs and alcohol, which can eventually lead to various liver disorders like hepatocellular, cholestatic (obstructive) or mixed type of liver disorders.( Kumar V et al. 2013)

The overall prevalence of Non Alcoholic Fatty Liver Disease (NAFLD) in western countries varies from 15-40\% and in Asian countries from $9-40 \%$. In India too, NAFLD is emerging as an important cause of liver disease. Epidemiological studies suggest the prevalence of NAFLD to be around 9-32\% in general Indian population, with a higher incidence amongst overweight / obese and diabetic/ pre diabetic patients. (Kalra S et al 2013) Moreover, nearly 119,000 cases of viral hepatitis were reported in India in 2012, which had been increased to 290,000 cases of acute viral hepatitis in 2013. (Chauhan LS 2014) This prevalence rate indicates that there is need to treat these disorders for human well being. Allopathic treatment shows significant result in the treatment of the hepatotoxicity but meanwhile it also tends to produce severe adverse effect to the body. Hence Ayurvedic formulations are in trend to treat the liver disorders.

Carbon tetrachloride $\left(\mathrm{CCl}_{4}\right)$ is a potent hepatotoxic chemical, has long been known as a model toxicant and has been the focus of many in vitro and in vivo toxicological studies. $\mathrm{CCl}_{4}$ is a wellknown hepatotoxin that is widely used to induce toxic liver injury in a range of laboratory animals. $\mathrm{CCl}_{4}$-induced hepatotoxicity is believed to involve two phases. The initial phase involves the metabolism of $\mathrm{CCl}_{4}$ by cytochrome $\mathrm{P}_{450}$ to the trichloromethyl radicals $\left(\mathrm{CCl}_{3}\right.$ and/or $\left.\mathrm{CCl}_{3} \mathrm{OO}\right)$, which lead to membrane lipid peroxidation and finally to cell necrosis. The second phase of $\mathrm{CCL}_{4}$-induced hepatotoxicity involves the activation of Kupffer cells, which is accompanied by the production of pro inflammatory mediators. (Sultana et al 2012, Ashour ben FM et al 2015). Standardization of herbal formulations is essential in order to assess the quality of drugs, base on the concentration of their active principles, physical and chemical standards. Standardization of the poly herbal formulation is possible by different modern scientific quality control procedures both for raw material and the finished product. The phytochemical constituents found to be present in the raw material used for the preparation of Polyherbal formulations possibly facilitate the desirable therapeutic efficacy of standardized medicinal formulation as a whole, and also could help in knowing the underlying mechanisms of the pharmacological action. (Patel D et al 2013) 
In present study various hepatoprotective formulations are used to treat liver toxicities. The constituents of the formulations show significant activity in Hepatotoxicity and liver disorders. Some of the ingredients possess the supporting activity to enhance the effect to treat liver disorders.

Tinospora cordifolia: it was proved to be effective in preventing fibrous changes and promoting regeneration by parenchymal tissue. It also helps in reduction of the liver weight and elevated serum level of SGPT, SGOT and Total Bilirubin.(Sinha K et al 2004, Kumar V et al 2013),1 1.

Phyllanthus amarus: Hepatoprotective effects of aqueous extract from Phyllanthus amarus on ethanol-induced rat hepatic injury were studied in vivo where the results reveal that treatment of rats with Phyllanthus amarus extract orally brought cell recovery in ethanol-induced liver injury by bringing the levels of aspartate transaminase (AST), alanine transaminase (ALT), high-sensitivity human thyroglobulin (HTG) and Tumor necrosis factor (TNF- $\alpha$ ) to normal. (Verma $S$ et al 2014).

Eclipta alba: The 6-weeks study reported significant reduction of serum triacylglycerol and total cholesterol, low-density lipoprotein-cholesterol levels and elevation in the high-density lipoprotein. (Chokotia LS et al 2013).

Tephrosia purpure: It can significantly reduce serum ALT, AST, ALP activity and increased total protein and reduced necrosis and inflammation in liver. Flavanoids present in T.purpure produces hepatocellular membrane stability, prevention of cellular leakage and increasing hepatic regeneration. (Gora RH et al 2014).

Boerhavia diffusa: The flavanoids present in Boerhavia diffusa may probably prevent the accumulation of excessive free radicals and protect the liver against paracetamol intoxication. Hepato protective activity of Boerhavia diffusa can have important chemical implications in the future treatment of liver disorders. Moreover, B.diffusa restored the creatinine level in paracetamol treated rats. (Venkatalakshmi P et al 2011).

Andrographis paniculata: Administration of the A. paniculata prevented hexachlorocyclohaxane induced hepatotoxicity in rats. Andrographolide, An active ingredient of the A. paniculata shows significant hepatoprotective effect against various types of liver damage. (Jarukamjorn K et al 2008).

Emblica officinalis: The altered biomarkers shows hepatotoxicity determined in serum, and liver were found to be attenuated by the E.officinalis in rats treated with chronic dose of $\mathrm{CCl}_{4}$. (Mir AI et al 2007).

Aloe barbadensis: Aloe vera also decreases the level of Alanine transaminase (ALT) or Serum glutamic pyruvic transaminase (SGPT) which indicates the restoration of normal functioning of Liver. It also protects the liver from oxidative stress and inhibits the excessive free radicals accumulations. It has liver protective effect against hepatotoxic agent by restoration of glutathione, glucose-6-phosphate and lipid peroxidation. (Sultana $\mathrm{N}$ et al 2012).

The current study aimed to further examine the effect of the various herbomineral formulations on Animal model to address its effect on Hepatotoxicity induced by the chemical toxic $\mathrm{CCl}_{4}$ in Albino rats.

\section{Materials and methods}

\subsection{Chemicals \& drugs}

The toxic substance $\mathrm{CCl}_{4}$, and Olive oil were obtained from the SHREE S. K. PATEL COLLEGE OF PHARMACEUTICAL EDUCATION \& RESEARCH, Kherva, Mehsana. The drug products and the T.cordifolia extract were obtained from the PETLAD MAHAL AROGYA MANDAL PHARMACY, Piplata, Nadiad.

\subsection{Animals}

Albino rats (Wistar strain) of both sex and weighing 150-200g were obtained from authorized animal house facility of the SHREE S. K. PATEL COLLEGE OF PHARMACEUTICAL EDUCATION \& RESEARCH, Kherva, Mehsana. The animals were housed in cages under controlled conditions of temperature $\left(25^{\circ} \mathrm{C}\right)$ and alternating 12 hour cycle of light and darkness. The animals had free access to standard rat pellet diet and tap water ad lib. After one week of acclimatization, the animals were considered suitable for study.

\subsection{Preparation of the plant extract \& other formula- tions}

The aerial plants of the Tinospora cordifolia and other five herbomineral formulations, i.e. Herbolive capsule, Herbolive Syrup, Hepatonej capsule, Hepatonej Syrup, and Hepanej Capsule are obtained from the PETLAD MAHAL AROGYA MANDAL PHARMACY, PIPLATA in December 2015. They were tested and authenticated in the QC laboratory of the same organization (India).

T. cordifolia Plant Materials was carefully segregated, washed and dried in shade. Dried stem and leaves of the plant were pulverized in an electric blender to form a powder. The prepared powder was kept in dry, clean, airtight glass jar and stored at $4{ }^{\circ} \mathrm{C}$ until used. $100 \mathrm{~g}$ of the prepared powder weighing was macerated and soaked in $500 \mathrm{ml}$ of distilled water for $24 \mathrm{~h}$. It was then filtered through a $1 \mathrm{~mm}$ mesh sieve and the filtrate was concentrated to a dark green residue by heating at $40^{\circ} \mathrm{C}$, till complete evaporation of water was achieved. The acute toxicity study of the Tinospora cordifolia was carried out on Swiss mice with a different dose range and at different body weight orally. From the results of this study, it is observed that there is no change in body weight, food and water consumption by the animals from all dose groups. There was no mortality recorded even at the highest dose level. (Pingale SS 2011). The constituents of the remaining formulations are as follows:

Table 1: Constituents of the 5 Hepatoprotective Formulation

\begin{tabular}{|c|c|c|}
\hline Formulations & Constituents & \\
\hline \multirow{16}{*}{ Herbolive Capsule } & Each Capsule contains: & \\
\hline & Ext.Tinospora cordifolia & $100 \mathrm{mg}$. \\
\hline & Ext.Phyllanthus fraternus & $80 \mathrm{mg}$. \\
\hline & Ext.Tephrosia Purpure & $60 \mathrm{mg}$. \\
\hline & Ext.Emblica officinalis & $60 \mathrm{mg}$ \\
\hline & Ext.Boerhavia diffusa & $20 \mathrm{mg}$. \\
\hline & Ext.Andographis Paniculata & $20 \mathrm{mg}$. \\
\hline & Ext.Aloe barbadensis & $10 \mathrm{mg}$. \\
\hline & Picrorhiza kurroa & $30 \mathrm{mg}$. \\
\hline & Zingiber officinale & $10 \mathrm{mg}$. \\
\hline & Piper nigrum & $10 \mathrm{mg}$. \\
\hline & Piper longum & $10 \mathrm{mg}$. \\
\hline & Plumbago zeylanica & $10 \mathrm{mg}$. \\
\hline & Yashad Bhasma & $6 \mathrm{mg}$ \\
\hline & Lauha Bhasma & $4 \mathrm{mg}$. \\
\hline & Shuddha Kasis & $5 \mathrm{mg}$. \\
\hline
\end{tabular}




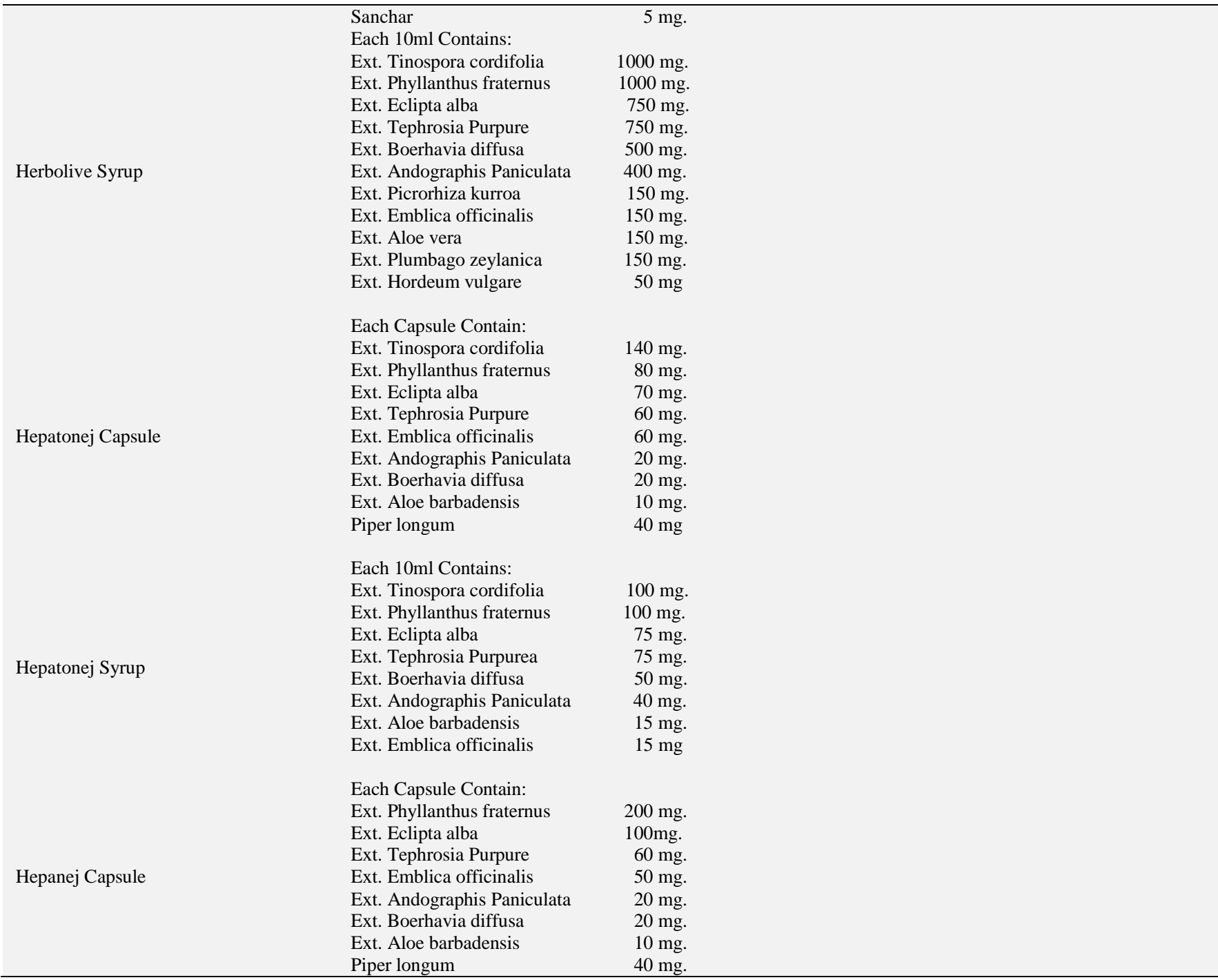

\subsection{Experimental design}

The experimental animals were divided in to 8 equal groups. The experiment was designed as follow:

\subsubsection{Study design}

- Group 1 (Normal Saline):- 5ml/1000gm twice daily normal saline in addition with standard rat pellet with tap water is administered orally for 20 days.

- Group $2\left(\mathrm{CCl}_{4}\right):-1 \mathrm{ml} / 1 \mathrm{~kg}$ of $50 \%$ of $\mathrm{v} / \mathrm{v}$ solution of the $\mathrm{CCl}_{4}$ in olive oil is administered I.P. once only on $20^{\text {th }}$ day.

- Group-3 (T.cordifolia extract):- $200 \mathrm{mg} / 1 \mathrm{~kg}$ twice daily is administered orally for 20 days followed by the $\mathrm{CCl}_{4}$ dose given I.P. concomitantly with last dose of Extract.

- Group-4 (Herbolive Syrup):- $5.4 \mathrm{ml} / 1 \mathrm{~kg}$ twice daily is administered orally for 20 days followed by $\mathrm{CCl}_{4}$ dose I.P. on last day with syrup.

- Group-5 (Hepatonej Syrup):- $5.4 \mathrm{ml} / 1 \mathrm{~kg}$ twice daily is administered orally for 20 days followed by $\mathrm{CCl}_{4}$ dose I.P. on last day with Extract.

- Group-6 (Hepanej Capsule):- $180 \mathrm{mg} / 1 \mathrm{~kg}$ twice daily is administered orally for 20 days followed by $\mathrm{CCl}_{4}$ dose I.P. on last day with Extract.

- Group-7 (Herbolive Capsule Extract):- $180 \mathrm{mg} / 1 \mathrm{~kg}$ twice daily is administered orally for 20 days followed by $\mathrm{CCl}_{4}$ dose I.P. on last day with extract.

- Group-8 (Hepatonej Capsule extract):- $180 \mathrm{mg} / 1 \mathrm{~kg}$ twice daily is administered orally for 20 days followed by $\mathrm{CCl}_{4}$ dose I.P. on last day with Extract.

\section{Result}

The organoleptic Properties and Quality test for finished products have been examined before conducting the efficacy preclinical trial. The Results of the Phyto chemical evaluation is shown in Table II and Table III.

The non-toxic nature of the T. cordifolia and other formulations reveals no lethality or toxic reactions on the treated animals at any doses till the end of the study period.

The average body weights of the different groups have been increased gradually due to proper intake of the food and Water for entire study period.

The diagnostic parameters of the hepatotoxicity like SGPT, SGOT, Total Bilirubin, Direct Bilirubin and ALP levels are examined in all different groups, and it revealed to be normal in normal saline group and drastically increased in $\mathrm{CCl}_{4}$ induced group (Disease Group). Five different formulations are used to treat the hepatotoxicity, which deliberately reduced the elevated levels of the SGPT, SGOT, Total bilirubin, direct bilirubin and Alanine phosphatase.

A highly significant rise in serum ALP levels was seen in $\mathrm{CCl}_{4}$ treated group $(186.667 \pm 63.025)$ compared to normal saline treated group (56.667 \pm 4.425$)$ at $p<0.01$. The rise in serum ALP was significantly lower $\mathrm{p}<0.01$ and $\mathrm{p}<0.05$ in other treated groups after $\mathrm{CCl}_{4}$ administration as compared to the group which received only $\mathrm{CCl}_{4}$ (disease control).

The administration of $\mathrm{CCl}_{4}$ (disease control) significantly increases the total bilirubin and direct bilirubin $(0.722 \pm 0.162$ and $0.317 \pm .0108$ respectively) as compared to normal saline treated 
group $(0.157 \pm 0.019$ and $0.043 \pm 0.015$ respectively) at $\mathrm{p}<0.001$. The rise in total bilirubin and direct bilirubin was significantly low in polyherbal formulations treated groups after $\mathrm{CCl}_{4}$ administration as compared to disease control group.

The administration of $\mathrm{CCl}_{4}$ (disease control) significantly increases the SGPT and SGOT level $(204 \pm 31.042$ and 199.5 \pm 16.211 respectively) as compared to normal saline treated group $(33 \pm 4.432$ and $64.5 \pm 6.19$ respectively) at $\mathrm{p}<0.001$. The elevated value of SGPT and SGOT was significantly low in polyherbal formulations treated groups after $\mathrm{CCL}_{4}$ administration as compared to disease control group.

Table 2: Organoleptic Properties

\begin{tabular}{|c|c|c|c|c|}
\hline No & Product Name & Color & Odor & Taste \\
\hline 1 & T.Cordifolia Extract & Dark Brown & Faint & Bitter \\
\hline 2 & Herbolive Syrup & Brown color Liquid & Aromatic & Sweetish Bitter \\
\hline 3 & Hepatonej Syrup & Brown color Liquid & Aromatic & Sweetish Bitter \\
\hline 5 & Herbolive Capsule & $\begin{array}{l}\text { Maroon/ Yellow color hard gelatin capsules contain- } \\
\text { ing light brown color powder }\end{array}$ & Faint & Bitter \\
\hline 6 & Hepatonej Capsule & $\begin{array}{l}\text { Maroon/ Yellow color hard gelatin capsules contain- } \\
\text { ing light brown color powder }\end{array}$ & Faint & Bitter \\
\hline
\end{tabular}

Table 3: Quality Test for the Finished Product and Plant Extract.

\begin{tabular}{|c|c|c|c|}
\hline Product Name & Quality Test & Specification & Result \\
\hline \multirow{4}{*}{ Herbolive Syrup } & Specific Gravity & $1.2000-1.3000 \mathrm{~g} / \mathrm{ml}$ & $1.249 \mathrm{~g} / \mathrm{ml}$ \\
\hline & $\mathrm{pH}$ & $4.0-6.0$ & 5.89 \\
\hline & Gross amount of Dry Extract & $55-65 \%$ from specified amount & $59.08 \%$ \\
\hline & Identification by TLC & As per Specification & Complies \\
\hline \multirow{5}{*}{ Hepatonej Syrup } & Specific Gravity & $1.2000-1.3000 \mathrm{~g} / \mathrm{ml}$ & $1.2229 \mathrm{~g} / \mathrm{ml}$ \\
\hline & $\mathrm{pH}$ & $4.0-6.0$ & 5.20 \\
\hline & Gross amount of Dry Extract & $55-65 \%$ from specified amount & $57.38 \%$ \\
\hline & Assay of Bitter & NLT0.2\% w/w & $0.54 \%$ \\
\hline & Identification by TLC & As per Specification & Complies \\
\hline \multirow{8}{*}{ Hepatonej Capsule } & Average weight of Capsule Content & $500.0 \mathrm{mg}$ & $503.10 \mathrm{mg}$ \\
\hline & Disintegration Time & NMT $15 \mathrm{~min}$ & $10.25 \mathrm{~min}$ \\
\hline & $\mathrm{LOD}$ at $110^{\circ} \mathrm{C}$ & NMT $7 \% \mathrm{w} / \mathrm{w}$ & $5.30 \%$ \\
\hline & Ash Content & NMT $18 \% w / w$ & $8.50 \%$ \\
\hline & Acid Insoluble Ash & NMT $7 \%$ w/w & $0.30 \%$ \\
\hline & Water Soluble Extract & NLT $35 \% \mathrm{w} / \mathrm{w}$ & $56.58 \%$ \\
\hline & Identification by TLC & As per Specification & Complies \\
\hline & Assay of Bitter & NLT $1 \% \mathrm{w} / \mathrm{w}$ & $2.10 \%$ \\
\hline \multirow{9}{*}{ Hepanej Capsule } & Average weight of Capsule Content & $500.0 \mathrm{mg}$ & $502.09 \mathrm{mg}$ \\
\hline & Disintegration Time & NMT $15 \mathrm{~min}$ & $10.39 \mathrm{~min}$ \\
\hline & $\mathrm{LOD}$ at $110^{\circ} \mathrm{C}$ & NMT $7 \% \mathrm{w} / \mathrm{w}$ & $4.59 \%$ \\
\hline & Ash Content & NMT $18 \% w / w$ & $8.55 \%$ \\
\hline & Acid Insoluble Ash & NMT 7\% w/w & $1.28 \%$ \\
\hline & Alcohol Soluble Extract & NLT $7 \% \mathrm{w} / \mathrm{w}$ & $15.89 \%$ \\
\hline & Water Soluble Extract & NLT $35 \% \mathrm{w} / \mathrm{w}$ & $49.56 \%$ \\
\hline & Identification by TLC & As per Specification & Complies \\
\hline & Assay of Bitter & NLT $1 \% \mathrm{w} / \mathrm{w}$ & $1.99 \%$ \\
\hline \multirow{7}{*}{ Herbolive Capsule } & Average weight of Capsule Content & $500.0 \mathrm{mg}$ & $501.29 \mathrm{mg}$ \\
\hline & Disintegration Time & NMT $15 \mathrm{~min}$ & $11.25 \mathrm{~min}$ \\
\hline & $\mathrm{LOD}$ at $110^{\circ} \mathrm{C}$ & NMT $7 \%$ w/w & $6.01 \%$ \\
\hline & Alcohol Soluble Extract & NLT $7 \%$ w/w & $14.75 \%$ \\
\hline & Water Soluble Extract & NLT $35 \% \mathrm{w} / \mathrm{w}$ & $51.22 \%$ \\
\hline & Identification by TLC & As per Specification & Complies \\
\hline & Assay of Bitter & NLT $1 \% \mathrm{w} / \mathrm{w}$ & $2.11 \%$ \\
\hline \multirow{7}{*}{ T.Cordifolia Extract } & $\mathrm{LOD}$ at $110^{\circ} \mathrm{C}$ & NMT $10 \% \mathrm{w} / \mathrm{w}$ & $4.20 \%$ \\
\hline & Total Ash & NMT $8 \% \mathrm{w} / \mathrm{w}$ & $3.36 \%$ \\
\hline & Acid Insoluble Ash & NMT $2 \%$ w/w & $0.46 \%$ \\
\hline & Alcohol Soluble Extract & NLT $35 \% \mathrm{w} / \mathrm{w}$ & $45.00 \%$ \\
\hline & Water Soluble Extract & NLT 70\%w/w & $88.54 \%$ \\
\hline & $\mathrm{pH}$ & 4 to 8 & 5.30 \\
\hline & Assay of Bitter & NLT $2 \% \mathrm{w} / \mathrm{w}$ & $2.30 \%$ \\
\hline
\end{tabular}


Table 4: Effect of Polyherbal Formulations and T.Cordifolia for the Duration of 20 Days on $\mathrm{Ccl}_{4}$ Induced Changes in Total Bilirubin \& Direct Bilirubin

\begin{tabular}{llll}
\hline Group & Treatment & Total Bilirubin $(\mathrm{mg} / \mathrm{dl})$ mean \pm SEM & Direct Bilirubin $(\mathrm{mg} / \mathrm{dl})$ mean \pm SEM \\
\hline I & Normal Saline & $0.157 \pm 0.019^{* * *}$ & $0.043 \pm 0.015^{* * *}$ \\
II & $\mathrm{CCl}_{4}(1 \mathrm{ml} / \mathrm{kg}$ I.P. & $0.722 \pm 0.162$ & $0.317 \pm 0.108$ \\
III & T.cordifolia $\times 20$ days $+\mathrm{CCl}_{4}$ on $20^{\text {th }}$ day & $0.320 \pm 0.096^{*}$ & $0.132 \pm 0.036^{*}$ \\
IV & Herbolive syrup 20 days $+\mathrm{CCl}_{4}$ on $20^{\text {th }}$ day & $0.298 \pm 0.073^{* *}$ & $0.135 \pm 0.018 *$ \\
V & Hepatonej Syrup $\times 20$ days $+\mathrm{CCl}_{4}$ on $20^{\text {th }}$ day & $0.320 \pm 0.052^{*}$ & $0.157 \pm 0.023$ \\
VI & Hepanej Capsule 20 days $+\mathrm{CCl}_{4}$ on $20^{\text {th }}$ day & $0.368 \pm 0.114^{*}$ & $0143 \pm 0.042$ \\
VII & Herbolive Capsule $\times 20$ days $+\mathrm{CCl}_{4}$ on $20^{\text {th }}$ day & $0.262 \pm 0.038^{* *}$ & $0.12 \pm 0.024 *$ \\
VIII & Hepatonej Capsule 20 days $+\mathrm{CCl}_{4}$ on $20^{\text {th }}$ & $0.177 \pm 0.025^{* * *}$ & $0.097 \pm 0.011 * *$ \\
& day &
\end{tabular}

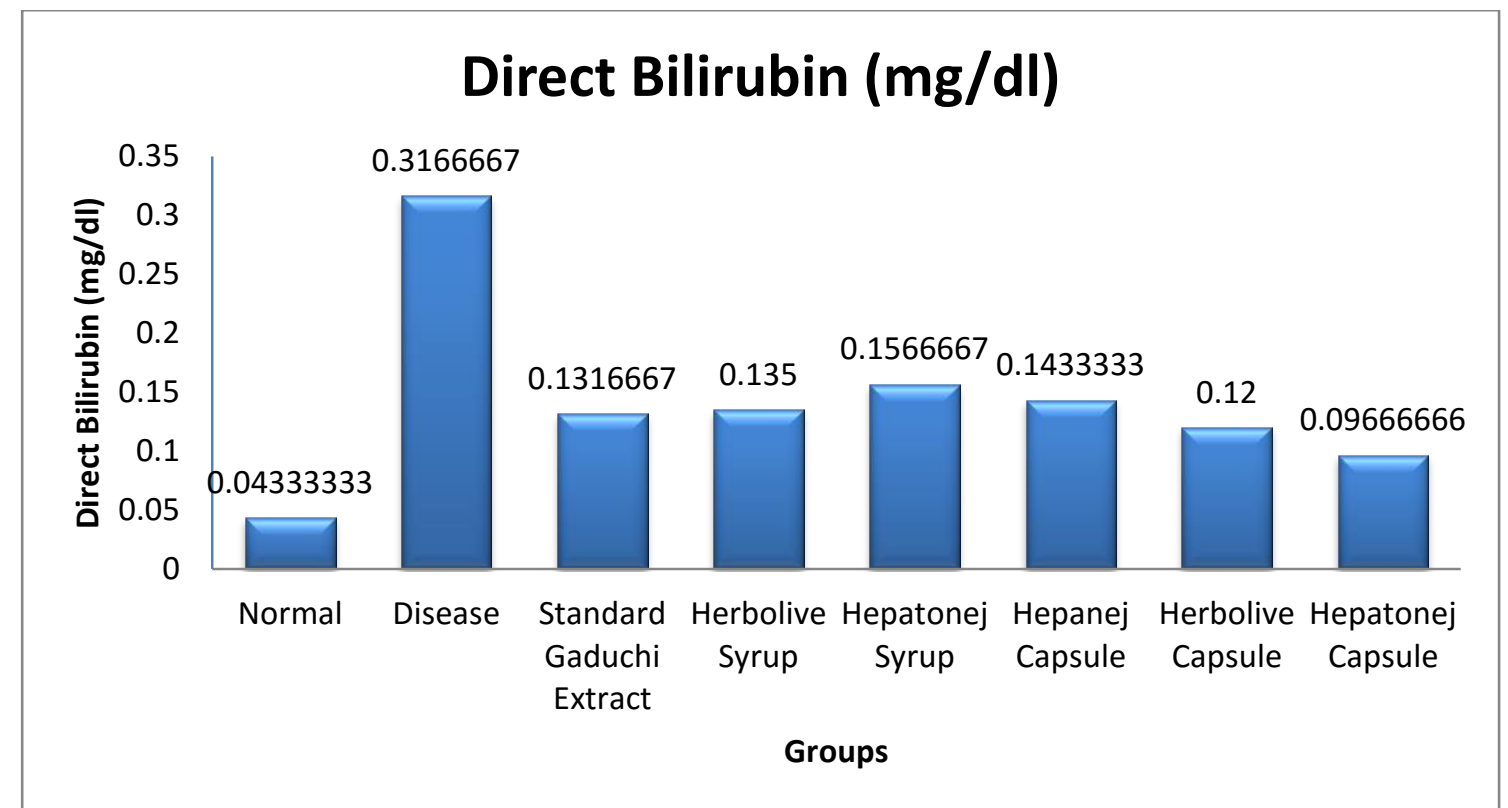

Fig. 1: Diagrammatic Representation of the Direct Bilirubin Level in Different Formulation Treatment Groups at Ccl4 Induced Animals

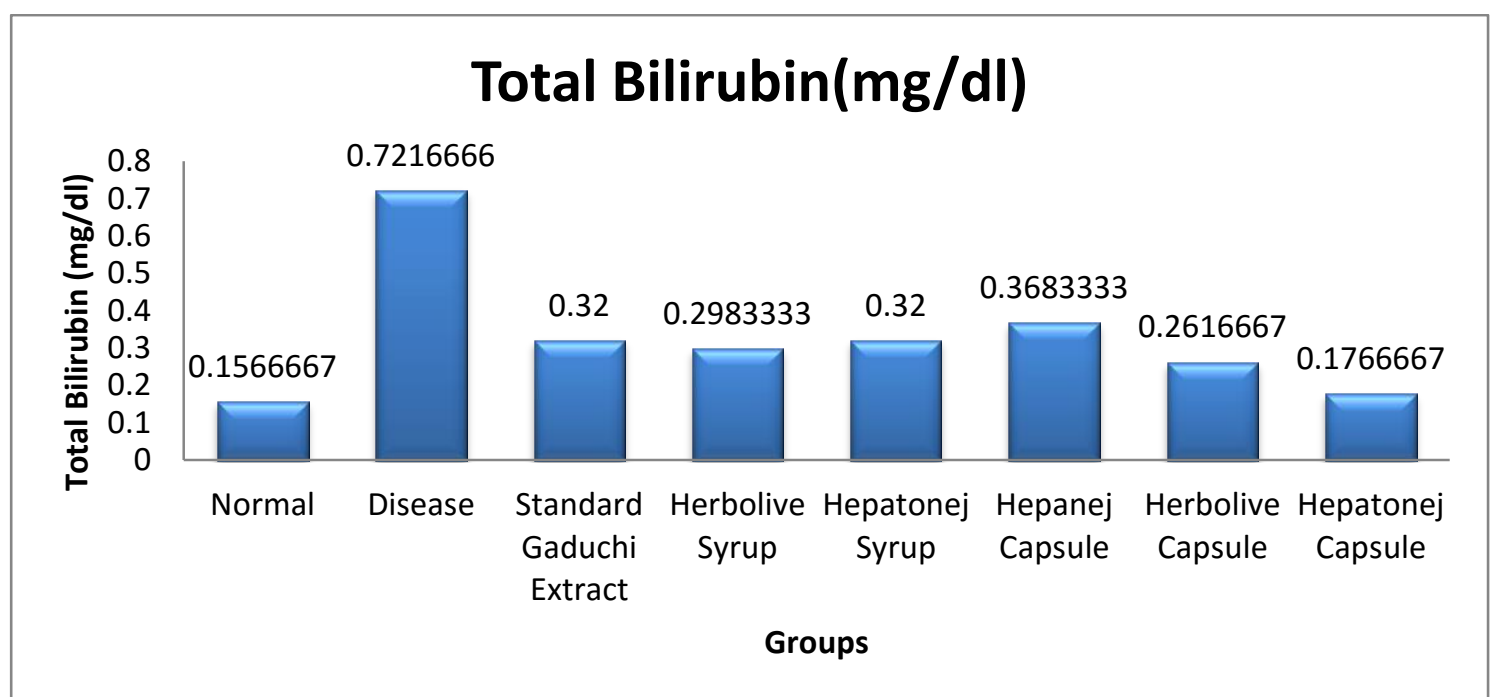

Fig. 2: Diagrammatic Representation of the Total Bilirubin Level in Different Formulation Treatment Groups at Ccl4 Induced Animals

Table 5: Effect of Polyherbal Formulations and T.Cordifolia for the Duration of 20 Days on $\mathrm{Ccl}_{4}$ Induced Changes in SGPT and SGOT Level

\begin{tabular}{|c|c|c|c|}
\hline Group & Treatment & SGPT (IU/L) mean \pm SEM & SGOT (IU/L) mean \pm SEM \\
\hline I & Normal Saline & $33 \pm 4.432 * * *$ & $64.5 \pm 6.19 * * *$ \\
\hline II & $\mathrm{CCl}_{4}(1 \mathrm{ml} / \mathrm{kg}$ I.P. $)$ & $204 \pm 31.042$ & $199.5 \pm 16.211$ \\
\hline III & T.cordifolia $\times 20$ days $+\mathrm{CCl}_{4}$ on $20^{\text {th }}$ day & $106.667 \pm 15.660 *$ & $117.83 \pm 12.533 *$ \\
\hline IV & Herbolive syrup $\times 20$ days $+\mathrm{CCl}_{4}$ on $20^{\text {th }}$ day & $100.833 \pm 30.611 * *$ & $109.333 \pm 25.147 * *$ \\
\hline V & Hepatonej Syrup $\times 20$ days $+\mathrm{CCl}_{4}$ on $20^{\text {th }}$ day & $113.833 \pm 21.688^{*}$ & $162.667 \pm 22.292$ \\
\hline VI & Hepanej Capsulex 20 days $+\mathrm{CCl}_{4}$ on $20^{\text {th }}$ day & $123.833 \pm 16.985$ & $139 \pm 22.451$ \\
\hline VII & Herbolive Capsule $\times 20$ days $+\mathrm{CCl}_{4}$ on $20^{\text {th }}$ day & $98.00 \pm 21.781 * *$ & $116.167 \pm 24.441 *$ \\
\hline VIII & Hepatonej Capsule $\times 20$ days $+\mathrm{CCl}_{4}$ on $20^{\text {th }}$ day & $55.833 \pm 11.253^{* * *}$ & $67.00 \pm 9.504 * * *$ \\
\hline
\end{tabular}

$* \mathrm{p}<0.05, * * \mathrm{p}<0.01, * * * \mathrm{p}<0.001$ as compared to $\mathrm{CCl}_{4}$ treated group 


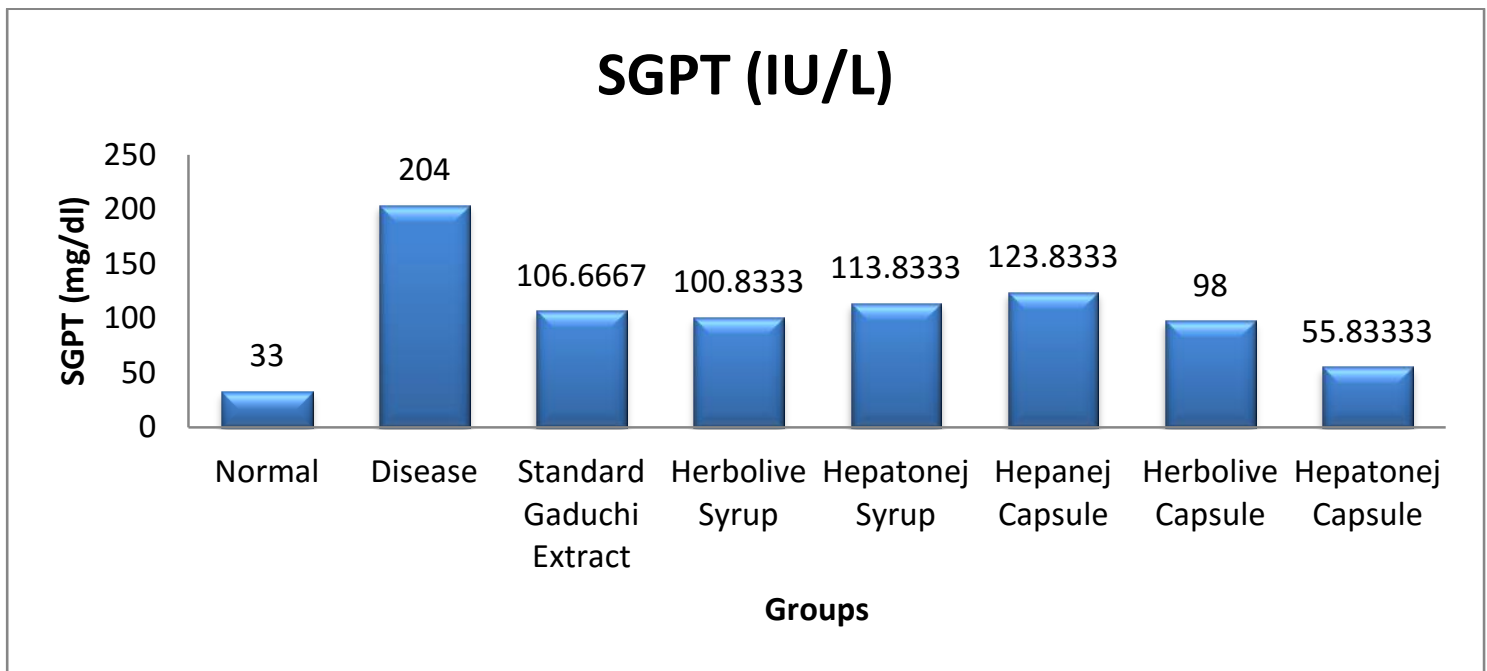

Fig. 3: Diagrammatic Representation of the SGPT Level in Different Formulation Treatment Groups at Ccl4 Induced Animals

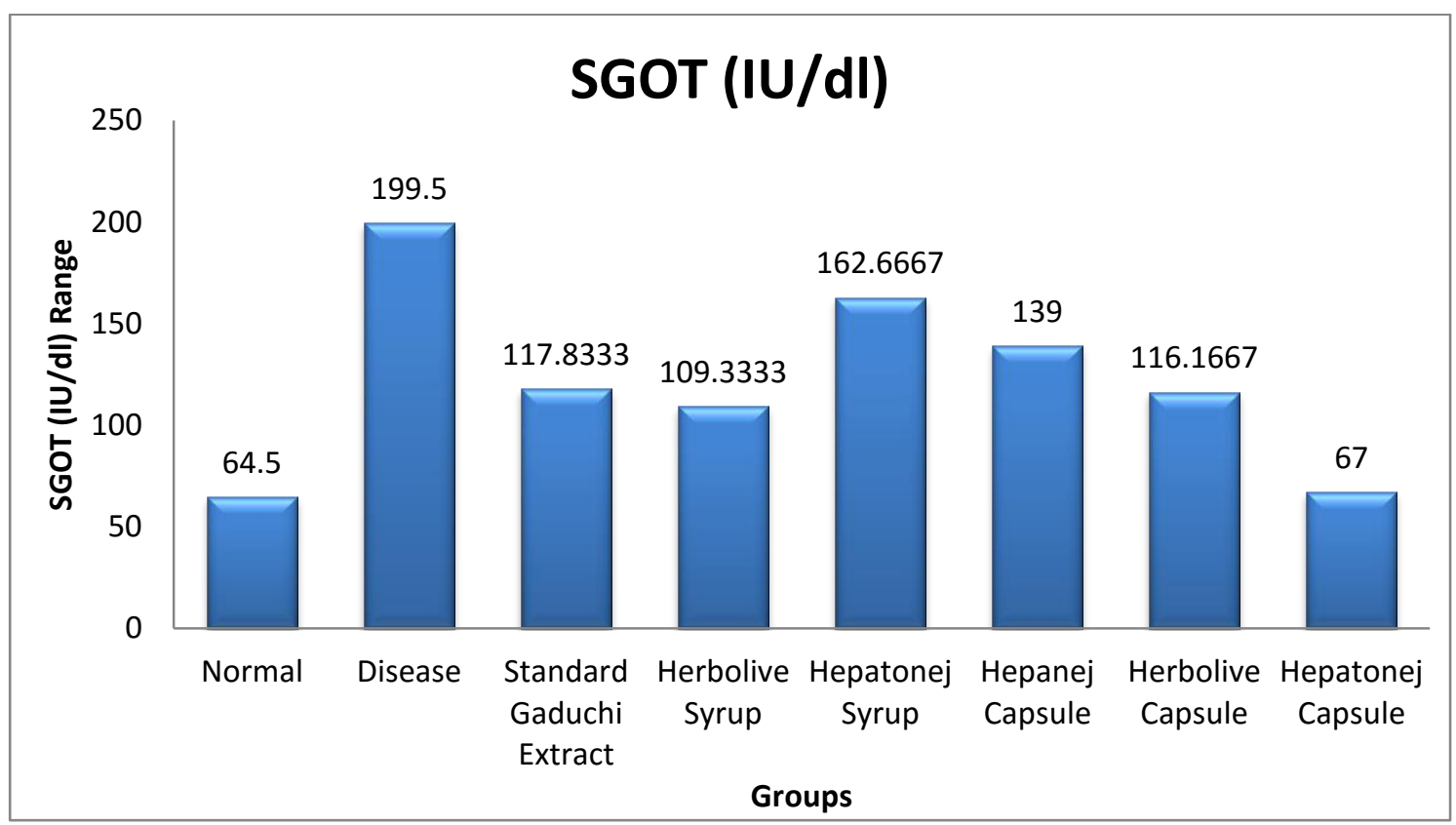

Fig. 4: Diagrammatic Representation of the SGOT Level in Different Formulation Treatment Groups at $\mathrm{Ccl}_{4}$ Induced Animals

Table 5: Effect of Polyherbal Formulations and T.Cordifolia for the Duration of 20 Days on $\mathrm{Ccl}_{4}$ Induced Changes in ALP Level

\begin{tabular}{|c|c|c|}
\hline Group & Treatment & $\begin{array}{l}\text { ALP (IU/L) } \\
\text { mean } \pm \text { SEM }\end{array}$ \\
\hline $\mathrm{I}$ & Normal Saline & $56.667 \pm 4.425 * *$ \\
\hline II & $\mathrm{CCl}_{4}(1 \mathrm{ml} / \mathrm{kg}$ I.P. $)$ & $186.667 \pm 63.025$ \\
\hline III & T.cordifolia $\times 20$ days $+\mathrm{CCl}_{4}$ on $20^{\text {th }}$ day & $69.00 \pm 10.770 * *$ \\
\hline IV & Herbolive syrup $\times 20$ days $+\mathrm{CCl}_{4}$ on $20^{\text {th }}$ day & $71.667 \pm 8.789 *$ \\
\hline V & Hepatonej Syrup $\times 20$ days $+\mathrm{CCl}_{4}$ on $20^{\text {th }}$ day & $75.667 \pm 8.924 *$ \\
\hline VI & Hepanej Capsule $\times 20$ days $+\mathrm{CCl}_{4}$ on $20^{\text {th }}$ day & $78.167 \pm 16.764 *$ \\
\hline VII & Herbolive Capsule $\times 20$ days $+\mathrm{CCl}_{4}$ on $20^{\text {th }}$ day & $61.667 \pm 12.449 * *$ \\
\hline VIII & Hepatonej Capsule $\times 20$ days $+\mathrm{CCl}_{4}$ on $20^{\text {th }}$ day & $54.00 \pm 10.263 * *$ \\
\hline
\end{tabular}




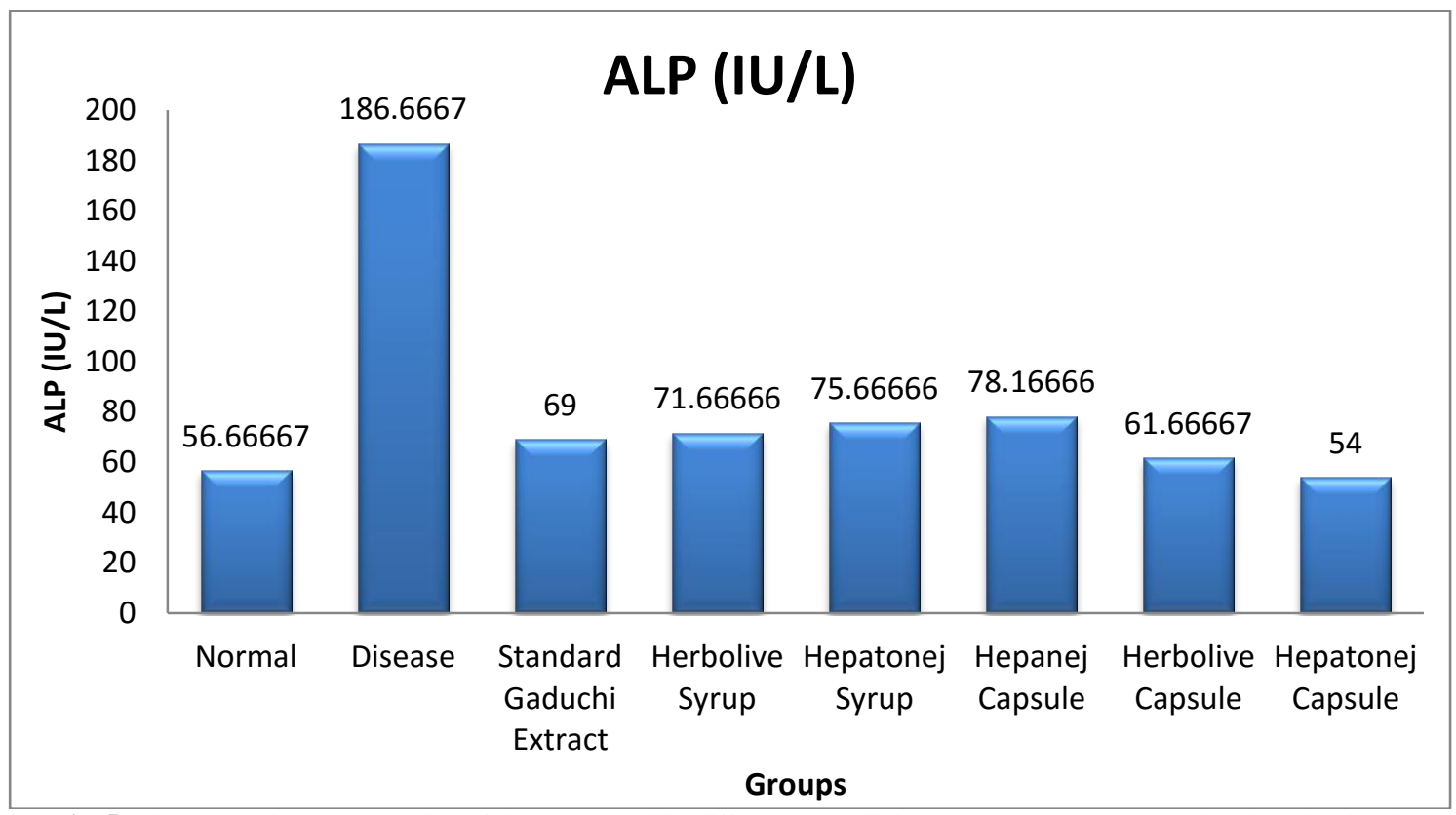

Fig. 5: Diagrammatic Representation of the ALP Level in Different Formulation Treatment Groups at $\mathrm{Ccl}_{4}$ Induced Animals

\section{Discussion}

In today's world liver, diseases become a global health problem, lacking helpful curative approach. There are so many plants that are used as a hepatoprotective agent in traditional medicine systems. (Arka G et al 2015).

It has been established that $\mathrm{CCl}_{4}$ is metabolically activated by cytochrome $\mathrm{P}_{450}$ - dependent mono-oxygenase to form highly reactive free radical metabolites, tri-chloro-methyl free radical $\left(\mathrm{CCl}_{3}\right)$ which later convert into more toxic tri-chloromethylperoxyl radical $\left(\mathrm{CCl}_{3} \mathrm{OO}^{-}\right)$in presence of oxygen. The same is capable to produce disturbance in the transport function of the hepatocytes which leads to leakage of enzymes (SGOT \& SGPT) from cells, hyper bilirubinaemia as well as increase in the level of serum ALP. (Sultana et al 2012, Ashour ben FM et al 2015).

Polyherbal formulations were subjected for various evaluation parameters with the analytical techniques. Polyherbal formulations composed of various plant ingredients, belonging to different families, different morphological plant parts and different phytoconstituents. The phytochemical analysis data suggested that capsule were consistent with various identity, quality, and purity parameters such as organoleptic parameters, physiochemical parameters, TLC profile.

The result of the present study reveals that the pre-treatment with different herbomineral formulations antagonizes elevated enzyme parameters. The tendency of these enzymes to return towards the normal range in these formulations administered groups was clearly indicating that the herbomineral formulations challenge to protect liver tissue from $\mathrm{CCl}_{4}$ injury. It was reported and accepted that serum levels of SGOT and SGPT return to almost normal with the healing of liver parenchyma and the regeneration of hepatocytes. (Osadebe PO et al 2012).

SGPT and SGOT were found to be significantly elevated after the $\mathrm{CCl}_{4}$ administration. The rise in Total bilirubin and direct bilirubin level were not to the same extent as SGPT and SGOT. Moreover, the ALP level is also markedly increased after the $\mathrm{CCl}_{4}$ administration to the animals. This could be explained by the fact that bilirubin reaches peak serum level in the second hour after $\mathrm{CCl}_{4}$ administration and probably declines afterwards. (Gumucio JJ 1989, Kumar V et al. 2013), Blood collection in the present study was 24 hours after $\mathrm{CCl}_{4}$ administration and thus, the serum bilirubin levels would have been on the decline. (Osadebe PO et al 2012).

\section{Conclusion}

It can be concluded from the present study is that $\mathrm{T}$. cordifolia has established potent hepatoprotective activity. Along with that the formulations used in present study also possess more significant hepatoprotective activity compared to single T. cordifolia compound. The Formulations has remarkably reduced the Elevated level of SGPT, SGOT, Total bilirubin, Direct Bilirubin and ALP up to almost normal level, which shows better hepatoprotective activity due to presence of the various hepatoprotective herbal plants extracts which synergies the action of the formulations and helps to treat the liver disorders more efficiently.

\section{Acknowledgment}

The present study was sponsored by the PETLAAD MAHAL AROGYA MANDAL PHARMACY, PIPLATA, and NADIAD. Data management, Biostatistical support and ethical committee approval was obtained from the SHREE S. K. PATEL COLLEGE OF PHARMACEUTICAL EDUCATION \& RESEARCH, Kherva, Mehsana.

\section{References}

[1] Kumar V, Modi PK, Saxena KK (2013) Exploration of Hepatoprotective activity of aqueous extract of Tinospora cordifolia- An Experimental Study. Asian journal of Pharmaceutical and Clinical Research 6(1), 87-91.

[2] Kalra S, Vithalani M, Gulati G, Kulkarni CM, Kadam Y, Pallivathukkal J, Das B, Sahay R, Modi KD (2013) Study of Prevalence of Non alcoholic Fatty Liver Disease (NAFLD) in Type-II Diabetes Patients in India (SPRINT). Journal of Association of Physicians of India 61, 448-453.

[3] Chauhan LS (2014) Hepatitis in India: Burden, Strategies, and Plans. NCDC News Letter 3(1).

[4] Ashour Ben FM, Alnagar FA, Treesh FA, Husien WMR, Alssaie MA, Alkholi MA (2015) Evaluation of the Protective Effects of Savliv Drops in CCL4- Induced Hepatic Fibrosis Albino Rats. Journal of Vaterinary Advances 4(9), 1105-1121. http://dx.doi.org/10.5455/jva.20150903025602.

[5] Patel D, Panchal M, Mavani H, Shah DR, Joshi S, Vyas B (2013) Phytochemical Screening and Standardization of Polyherbal Formulation "RIPARE" for Arthritis. International journal of Pharma Research \& Review 2(6), 29-35.

[6] Verma S, Sharma H, Garg M (2014) Phyllanthus amarus: A Review. Journal of Pharmacognosy and Phytochemistry, 3(2), 18-22. 
[7] Chokotia LS, Vashistha P, Sironiya R, Matoli H (2013) Pharmacological Activities of Eclipta Alba (L.). International Journal of Research and Development in Pharmacy and Life Sciences 2(4), 499502.

[8] Gora RH, Baxla SL, Kerketta P, Patnaik S, Roy BK (2014) Hepatoprotective activity of Tephrosia purpure against arsenic induced toxicity in Rats. Indian Journal of Pharmacology 46(2), 197-200. http://dx.doi.org/10.4103/0253-7613.129317.

[9] Venkatalakshmi P, Vallabi E, Netaji S (2011) Hepatoprotective Activity of Boerhavia diffusa against Paracetamol induced toxicity in rats. Journal of chemical and pharmaceutical research 3(6), 229-232.

[10] Jarukamjorn K, Nemoto N (2008) Pharmacological aspects of Andrographis paniculata on health and its major diterpenoid constituents Andrographolide. Journal of health science 54(4), 370-81. http://dx.doi.org/10.1248/jhs.54.370.

[11] Mir AI, Kumar B, Tasduq SA, Gupta DK, Bhardwaj S, Johri RK (2007) Reversal of Hepatotoxin-induced pre-fibrogenic events by Emblica officinalis- A histological study. Indian journal of Experimental Biology 45, 626-629.

[12] Sultana N, Najam R (2012) Gross toxicities and hepatoprotective effect of Aloe vera (L) Burm.F. International research journal of Pharmacy 3(10), 106-110.

[13] Pingale SS (2011) acute tocxicity study for Tinospora Cordifolia International journal of Research in Ayurveda and Pharmacy 2(5), $1571-1573$

[14] Arka G, Kundu A, Seth A, Singh AK, Maurya SK (2015) Preliminary evaluation of hepatoprotective potential of the polyherbal formulation. Journal of Intercultural Ethnopharmacology 4(2), 118124.

[15] Osadebe PO, Okoye FB, Uzor PF, Nnamani NR, Adiele IE, Obiano NC (2012) Phytochemical analysis, hepatoprotective and antioxidant activity of Alchornea cordifolia methanol leaf extract on carbon tetrachloride-induced hepatic damage in rats. Asian Pac J Trop Med 5(4), 289-293. http://dx.doi.org/10.1016/S19957645(12)60041-8.

[16] Gumucio JJ (1989) Hepatocyte heterogeneity: The coming of age from the description of a biological curiosity to a partial understanding of its physiological meaning and regulation. Hepatology 9 , 154-60. http://dx.doi.org/10.1002/hep.1840090124. 